\title{
Natural products isolated from Tetragonula carbonaria cerumen modulate free radical- scavenging and 5-lipoxygenase activities in vitro
}

\author{
Karina D. Hamilton ${ }^{1}$, Peter R. Brooks ${ }^{1,2}$, Steven M. Ogbourne ${ }^{2}$ and Fraser D. Russell ${ }^{1 *}$
}

\begin{abstract}
Background: Propolis and cerumen are plant-derived products found in honeybees and stingless bees, respectively. Although propolis is an ancient folk medicine, the bioactivities of cerumen obtained from Australian native stingless bees (Tetragonula carbonaria) have not been widely studied. Therefore, we investigated selected anti-oxidant and antiinflammatory properties of $T$. carbonaria cerumen.

Methods: A methanolic extract was prepared from the combined cerumen of $40 \mathrm{~T}$. carbonaria hives, and HPLC was used to screen for chemical constituents that scavenged 2,2-azobis(2-methylpropionamidine) dihydrochloride (AAPH). The ability of cerumen extracts to scavenge 1,1-diphenyl-2-picrylhydrazyl (DPPH) and to interfere with leukotriene $B_{4}$ $\left(\mathrm{LTB}_{4}\right)$ production in ionomycin-stimulated human neutrophils was also examined.

Results: The extract dose-dependently scavenged DPPH $\left(\mathrm{EC}_{50}=27.0 \pm 2.3 \mu \mathrm{g} / \mathrm{mL}\right)$; and inhibited the 5-lipoxygenase (5-LOX)-mediated oxidation of linoleic acid $\left(\mathrm{IC}_{50}=67.1 \pm 9.6 \mu \mathrm{g} / \mathrm{mL}\right)$. Pre-treatment of isolated human neutrophils with the methanolic cerumen extract additionally inhibited the ionomycin-stimulated production of $\mathrm{LTB}_{4}$ from these cells $\left(\mathrm{IC}_{50}=13.3 \pm 5.3 \mu \mathrm{g} / \mathrm{mL}\right)$. Following multi-solvent extraction, the free radical-scavenging and 5-LOX-inhibiting activities of the initial cerumen extract were retained in a polar, methanol-water extract, which contained gallic acid and a range of flavonone and phenolic natural products.

Conclusions: The findings identify free radical scavenging activity, and interference by extracts of $T$. carbonaria cerumen in 5-LOX-LTB 4 signaling. Further investigation is needed to determine whether the extracts will provide therapeutic benefits for medical conditions in which oxidative stress and inflammation are implicated, including cardiovascular disease and impaired wound healing.
\end{abstract}

Keywords: Propolis, Tetragonula carbonaria, Inflammation, 5-lipoxygenase, Free radical-scavenging

\section{Background}

Propolis is a resinous, plant-derived natural product of honeybees; made by foraging for plant resins and combining these with beeswax and salivary secretions [1]. Cerumen is a similar material produced by stingless bees of the Meliponini tribe [2]. Cerumen and propolis contain chemical constituents that protect the hive

\footnotetext{
* Correspondence: FRussell@usc.edu.au

${ }^{1}$ Inflammation and Healing Research Cluster, Faculty of Science, Health,

Education and Engineering, School of Health and Sport Sciences, University

of the Sunshine Coast, Maroochydore, QLD 4558, Australia

Full list of author information is available at the end of the article
}

against bacterial infection and opportunistic pests [1, 2]. Although propolis and cerumen typically comprise $50 \%$ plant resin, 30\% beeswax, 10\% essential and aromatic oils, $5 \%$ pollen and $5 \%$ organic debris $[1,3]$, their exact chemical compositions may vary widely.

Propolis treatment has traditionally been indicated for a wide range of ailments, which has more recently been attributed to the broad anti-oxidant, anti-cancer, antibacterial, anti-viral, anti-inflammatory and woundhealing effects of its extracts (reviewed in [1, 4]). These properties have often been correlated with a relatively small number of compounds in the sample or extract, 
including caffeic acid phenethyl ester (CAPE), artepillin C, kaempferol and galangin [5-8]. However, other studies have identified novel constituents within propolis extracts that are responsible for some of its observed bioactivities [9-12].

Tetragonula carbonaria is a stingless bee species native to Australia and commonly inhabits the Eastern coastline of southern Queensland and northern New South Wales [13]. T. carbonaria produce cerumen using the resins of the turpentine tree (Syncarpia glomulifera) [14] and Cadaghi gum (Corymbia torelliana) [15, 16]. Our research group has shown that a methanolic extract of $T$. carbonaria cerumen comprises polar constituents including gallic acid, amyrins, $C$-methyl flavanones and phloroglucinols, amongst others [17-19]. This extract, which has a chemical profile distinct to typical honeybee propolis [17], elicited a vasorelaxant response in precontracted human and porcine artery preparations [20] and exerted antibacterial activity against Staphylococcus aureus $[18,19]$. An ethanolic extract of $T$. carbonaria cerumen inhibited 5-lipoxygenase (5-LOX) activity in a cell-free assay [17], although the kinetics for this response was not determined. Following on from this work, the aim of the present study was to investigate additional anti-oxidant and anti-inflammatory properties of $T$. carbonaria cerumen extracts. In particular, cellfree assays tested the potential of cerumen extracts to scavenge free radicals and inhibit the pro-inflammatory enzyme, 5-lipoxygenase (5-LOX). Stimulated human neutrophils additionally served as an in vitro model of human inflammation, to test the effects of a $T$. carbonaria cerumen extract on the 5-LOX mediatedproduction of the pro-inflammatory eicosanoid, leukotriene $\mathrm{B}_{4}\left(\mathrm{LTB}_{4}\right)$.

\section{Methods}

\section{Cerumen collection and methanolic extraction}

Cerumen collected from $40 \mathrm{~T}$. carbonaria hives in the Brisbane region of South-East Queensland, Australia, was washed with water to remove debris and homogenised into one bulk sample. Raw $T$. carbonaria cerumen was extracted in $10 \mathrm{~mL}$ methanol and $5 \mathrm{~mL}$ hexane (per gram) with tumbling at $15 \mathrm{rpm}$ and $22{ }^{\circ} \mathrm{C}$ for $24 \mathrm{~h}$. Following paper filtration, waxes contained in the upper hexane extract were discarded, and the remaining methanolic extract was evaporated under nitrogen gas $\left(\mathrm{N}_{2}\right)$ and freeze-dried overnight. Dried extract was reconstituted in dimethyl sulfoxide (DMSO; $1-500 \mu \mathrm{g} / \mathrm{mL}$ ) for activity testing.

\section{Multi-solvent extraction of the methanolic cerumen extract} Hexane $(15 \mathrm{~mL})$ was added to the initial methanolic extract $(30 \mathrm{~mL})$, and the 'first' hexane extract was collected. Distilled water $(15 \mathrm{~mL})$ was then added to the remaining methanolic extract, which was extracted once more with hexane $(20 \mathrm{~mL})$. The 'second' hexane extract was separated from the methanol-water extract; both of which were collected. The two hexane extracts and the methanol-water extract obtained were evaporated under $\mathrm{N}_{2}$, freeze-dried and reconstituted in DMSO (1-5000 $\mu \mathrm{g} / \mathrm{mL})$ for activity testing (Fig. 1).

\section{Collection and isolation of human neutrophils}

Neutrophils were isolated from whole blood samples collected from healthy consenting adults, who were recruited to the study through internal advertisements at the University of the Sunshine Coast (USC). Persons who had recently taken medications known to affect neutrophil function (e.g. NSAIDs and, glucocorticoids), ingested alcohol or had undertaken strenuous exercise $48 \mathrm{~h}$ prior to blood collection, smoked regularly, or were pregnant, were excluded from the study. Whole blood was collected from healthy volunteers who provided their informed consent, and with ethics approval from the USC Human Research Ethics Committee (S/12/389). Blood collection followed the guidelines of the Declaration of Helsinki and Tokyo for humans.

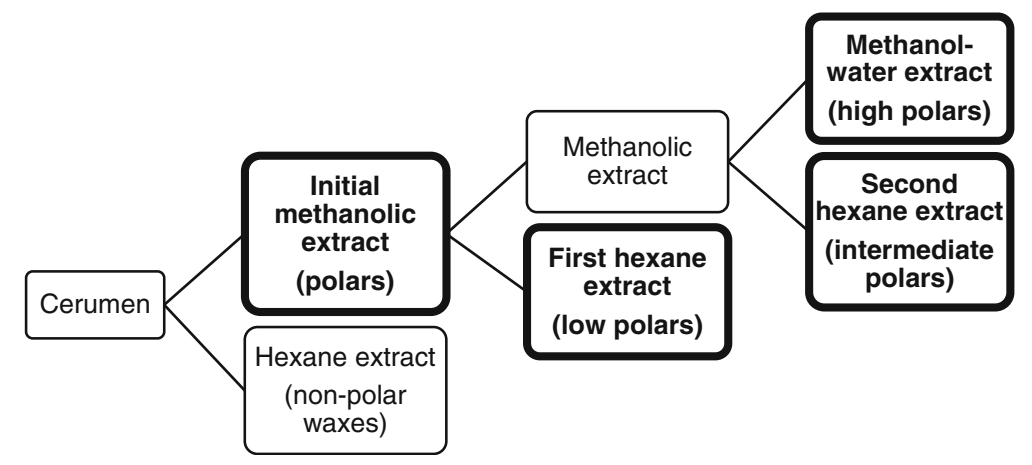

Fig. 1 Multi-solvent extraction of T. carbonaria cerumen. Cerumen was partitioned into extracts of increasing polarity. Extracts in bold were collected, dried and tested for free radical-scavenging activity and 5-LOX inhibition 
Venous blood $(12 \mathrm{~mL})$ was collected from the median cubital vein of four consenting individuals (24-62 years) into $\mathrm{K}_{2}$ EDTA tubes. Neutrophils were obtained by layering $5 \mathrm{~mL}$ of whole blood onto $5 \mathrm{~mL}$ of Polymorphprep solution (Axis-Shield; Oslo, Norway) and centrifuging at $500 \times g$ for $30 \mathrm{~min}$. The clear blood fraction containing neutrophils was collected into another centrifuge tube containing $6 \mathrm{~mL}$ of '20\% media' (Media 199 containing $20 \%$ foetal bovine serum (FBS), $50 \mu \mathrm{g} / \mathrm{mL}$ penicillin/ streptomycin and $2 \mathrm{mM}$ Glutamax-I) and centrifuged a second time at $500 \times g$ for $6 \mathrm{~min}$. The cell pellets were resuspended in $1.3 \mathrm{~mL}$ of Dulbecco's PhosphateBuffered Saline (PBS), with $10 \mu \mathrm{L}$ of sample smeared onto a microscope slide and stained using Diff Quik differential dye to confirm successful isolation of neutrophils using brightfield microscopy.

\section{High-performance liquid chromatography (HPLC) screening of free radical-scavenging constituents} Anti-oxidant compounds within the methanolic extract of T. carbonaria cerumen were identified using a modified HPLC screening method [21], using 2,2-azobis(2-methylpropionamidine) dihydrochloride (AAPH) as a free radical initiator. Dried methanolic $T$. carbonaria cerumen extracts $(4 \mathrm{mg} / \mathrm{mL})$ and AAPH $(160 \mathrm{mg} / \mathrm{mL})$ were reconstituted in 1:1 MilliQ water:acetonitrile, and equal volumes of each solution were incubated at $40{ }^{\circ} \mathrm{C}$. After $8 \mathrm{~h}$, reversed-phase HPLC analysis of samples was performed using a PerkinElmer Series 200 HPLC pump and auto-sampler, with a Phenomenex Synergi $4 \mu \mathrm{m}$ FusionRP $80 \AA$ analytical column, $75 \times 4.6 \mathrm{~mm}$ with $4 \mu \mathrm{m}$ particles (Phenomenex, Inc.; Lane Cove, NSW, Australia). Mobile phase A (MPA) was 95:5 MilliQ water:acetonitrile and mobile phase B (MPB) was 10:90 MilliQ water:acetonitrile. Following $1 \mathrm{~min}$ equilibration at 100\% MPA; $1.2 \mathrm{~mL} / \mathrm{min}$ ), samples were eluted with the following method: $100 \%$ MPA for $2 \mathrm{~min}$, graded to 50:50 MPA:MPB over $10 \mathrm{~min}$, $100 \% \mathrm{MPB}$ for $20 \mathrm{~min}, 100 \% \mathrm{MPB}$ for $10 \mathrm{~min}$, graded back to $100 \%$ MPA over $5 \mathrm{~min}, 100 \mathrm{MPA}$ for $3 \mathrm{~min}$ (total run time $=50 \mathrm{~min}$ ). Photodiode array detection occurred at 205, 260, 290 and $340 \mathrm{~nm}$. Constituents of the extract that scavenged AAPH-derived free radicals were detected by the reduction or disappearance of the peak intensity for the compound following HPLC analysis. An AAPHnegative control containing $2 \mathrm{mg} / \mathrm{mL}$ extract in 1:1 MilliQ water:acetonitrile was also included in the assay, and additional analyses confirmed that deterioration of the samples did not occur over $8 \mathrm{~h}$ (not shown).

\section{Colorimetric 1,1-diphenyl-2-picrylhydrazyl (DPPH) assay}

Reconstituted extracts of $T$. carbonaria cerumen were incubated with $100 \mu \mathrm{M}$ DPPH (prepared in methanol) for $30 \mathrm{~min}$ at $22{ }^{\circ} \mathrm{C}$, then absorbance was measured at $518 \mathrm{~nm}$. DPPH-scavenging activity of each sample was calculated by measuring the decline in absorbance after $30 \mathrm{~min}$, and expressed as a percentage of a negative control.

\section{Cell-free 5-LOX assay}

The inhibitory effect of $T$. carbonaria cerumen on the 5-LOX-mediated oxidation of linoleic acid was examined using a modified colorimetric assay [22]. Briefly, $10 \mu \mathrm{L}$ of each reconstituted cerumen extract was added to $0.5 \mathrm{~mL}$ of Solution A (containing $10 \mathrm{mM} \mathrm{3-}$ (dimethylamino)benzoic acid, $0.05 \mathrm{M}$ disodium phosphate $\left(\mathrm{Na}_{2} \mathrm{HPO}_{4} ; \mathrm{pH}\right.$ 6.0), $500 \mu \mathrm{M}$ linoleic acid) and 5-LOX enzyme (3.4 $\mu \mathrm{g}$ in $10 \mu \mathrm{L}$ water), then incubated for $5 \mathrm{~min}$ at $22{ }^{\circ} \mathrm{C}$. Solution B $(0.5 \mathrm{~mL})$, containing $10 \mathrm{mM}$ 3-methyl-2-benzothiazolinone and $0.1 \mathrm{mg} / \mathrm{mL}$ haemoglobin was added and incubated for a further $5 \mathrm{~min}$ at $22{ }^{\circ} \mathrm{C}$. Samples were centrifuged at $20,000 \times \mathrm{g}$. for $3 \mathrm{~min}$ at $22{ }^{\circ} \mathrm{C}$, and the absorbance of the supernatant was measured at $590 \mathrm{~nm}$. Inhibition of 5LOX by each sample was calculated by measuring the decline in absorbance after $30 \mathrm{~min}$, and expressed as a percentage of a negative control.

The effect of the methanolic cerumen extract on 5-LOX enzyme kinetics was also determined. Reconstituted extract $(10 \mu \mathrm{L}$; final concentration $100 \mu \mathrm{g} / \mathrm{mL}$ ) was added to equal volumes of Solution A (containing 10-500 $\mu \mathrm{M}$ linoleic acid) and Solution B, then aliquotted into a 96-well microplate. Absorbance at $590 \mathrm{~nm}$ was measured immediately after the addition of 5 -LOX $(1.7 \mu \mathrm{g}$ in $5 \mu \mathrm{L}$ water), and periodically over one hour. The mean maximal reaction velocity $\left(\mathrm{V}_{\text {max }}\right)$ and Michaelis constant $\left(\mathrm{K}_{\mathrm{m}}\right)$ were calculated for 5-LOX activity in the absence and presence of cerumen extract.

\section{$\mathrm{LTB}_{4}$ production in isolated human neutrophils}

Resuspended neutrophils (35 $\mu \mathrm{L}$ ) were made up to $70 \mu \mathrm{L}$ with Dulbecco's PBS containing methanolic cerumen extract (final concentration 1-500 $\mu \mathrm{g} / \mathrm{mL}$ ). Cell suspensions were incubated at $37{ }^{\circ} \mathrm{C}$ in a $5 \%$ $\mathrm{CO}_{2}$ incubator for $20 \mathrm{~min}$, then treated with $2 \mu \mathrm{M}$ ionomycin for a further $5 \mathrm{~min}$ (final reaction volume $80 \mu \mathrm{L})$ to stimulate $\mathrm{LTB}_{4}$ production [23]. Samples were centrifuged at $40 \times g$ for $6 \mathrm{~min}$ at $22{ }^{\circ} \mathrm{C}$, and $\mathrm{LTB}_{4}$ concentration was determined spectrophotometrically at $405 \mathrm{~nm}$ using $50 \mu \mathrm{L}$ aliquots of the supernatant in a $\mathrm{LTB}_{4}$ ELISA, according to manufacturer's instructions (Cayman Chemical Company; Ann Arbor, USA). Background absorbance was measured in the absence of ionomycin and subtracted from all readings. Solvent ( $1 \%$ DMSO) and untreated controls were included in each assay, and were without effect (not shown). 


\section{HPLC analysis of methanol-water extract}

A sample of the methanol-water extract was analysed with reversed-phase HPLC using a Synergi $4 \mu \mathrm{m}$ FusionRP $80 \AA$ A $75 \times 4.6 \mathrm{~mm}$ column (Phenomenex Inc.; Lane Cove, NSW, Australia). MPA was 95:5 MilliQ water:acetonitrile (Honeywell Burdick and Jackson ${ }^{\circ}$, SA, Australia) and $\mathrm{MPB}$ was 10:90 MilliQ water:acetonitrile. Following $1 \mathrm{~min}$ equilibration (100\% MPA; $1.2 \mathrm{~mL} / \mathrm{min}$ ), samples were separated with the following method: 100\% MPA for $2 \mathrm{~min}$, graded to 50:50 MPA:MPB over $10 \mathrm{~min}$, graded to $100 \% \mathrm{MPB}$ over $20 \mathrm{~min}, 100 \% \mathrm{MPB}$ for $10 \mathrm{~min}$, graded to $100 \% \mathrm{MPA}$ over $5 \mathrm{~min}, 100 \% \mathrm{MPA}$ for $3 \mathrm{~min}$ (total run time $=50 \mathrm{~min}$ ). Detection occurred at 205,260, 290 and $340 \mathrm{~nm}$. Major constituents were identified where possible, by comparison to known compounds.

\section{Data analysis}

Data are expressed as mean \pm SEM. Data were compared using one way ANOVA with Tukey's post-hoc test, where differences were considered significant at $P<0.05$.

\section{Results}

Free radical-scavenging activities of $T$. carbonaria cerumen extracts

Polar extracts of $T$. carbonaria cerumen displayed free radical-scavenging properties in vitro. Reversed-phased HPLC screening of the methanolic cerumen extract identified several free radical-scavenging constituents, evidenced by reduced peak intensities after reacting with the free radical initiator, APPH (Fig. 2). The extract also scavenged DPPH, in a dose-dependent manner $\left(\mathrm{EC}_{50}=27.0 \pm 2.3 \mu \mathrm{g} / \mathrm{mL}\right.$; Fig. 3). Following multisolvent partitioning of the methanolic extract, DPPHscavenging activity was identified in the resultant methanol-water and hexane extracts. However, the potency of this activity was significantly greater in the methanol-water extract $\left(\mathrm{EC}_{50}=31.1 \pm 1.6 \mu \mathrm{g} / \mathrm{mL}\right)$ than the first and second hexane extracts $\left(\mathrm{EC}_{50}=352.2 \pm 7.1 \mu \mathrm{g} / \mathrm{mL}\right.$ and $128.1 \pm 16.9 \mu \mathrm{g} / \mathrm{mL}$ respectively; $P<0.05)$.

Effect of $T$. carbonaria cerumen extracts on 5-LOX activity and neutrophil-derived $\mathrm{LTB}_{4}$

Similar to its DPPH-scavenging activity, the inhibitory effect of the methanolic cerumen extract on cell-free 5LOX activity was dose-dependent $\left(\mathrm{IC}_{50}=67.1 \pm 9.6 \mu \mathrm{g} /\right.$ $\mathrm{mL}$; Fig. 4a). The kinetics of linoleic acid oxidation by $5-$ LOX $\left(\mathrm{V}_{\max }=0.08 \pm 0.006\right.$ absorbance units $/ \mathrm{min}$; $\left.\mathrm{K}_{\mathrm{m}}=71.3 \pm 10.4 \mu \mathrm{M}\right)$ were significantly altered in the presence of $100 \mu \mathrm{g} / \mathrm{mL}$ extract $\left(\mathrm{V}_{\max }=0.04 \pm 0.002\right.$ absorbance units $/ \mathrm{min} ; \mathrm{K}_{\mathrm{m}}=115.0 \pm 7.3 \mu \mathrm{M} ; P<0.05$; Fig. $4 \mathrm{~b})$. The extract also inhibited ionomycin-induced
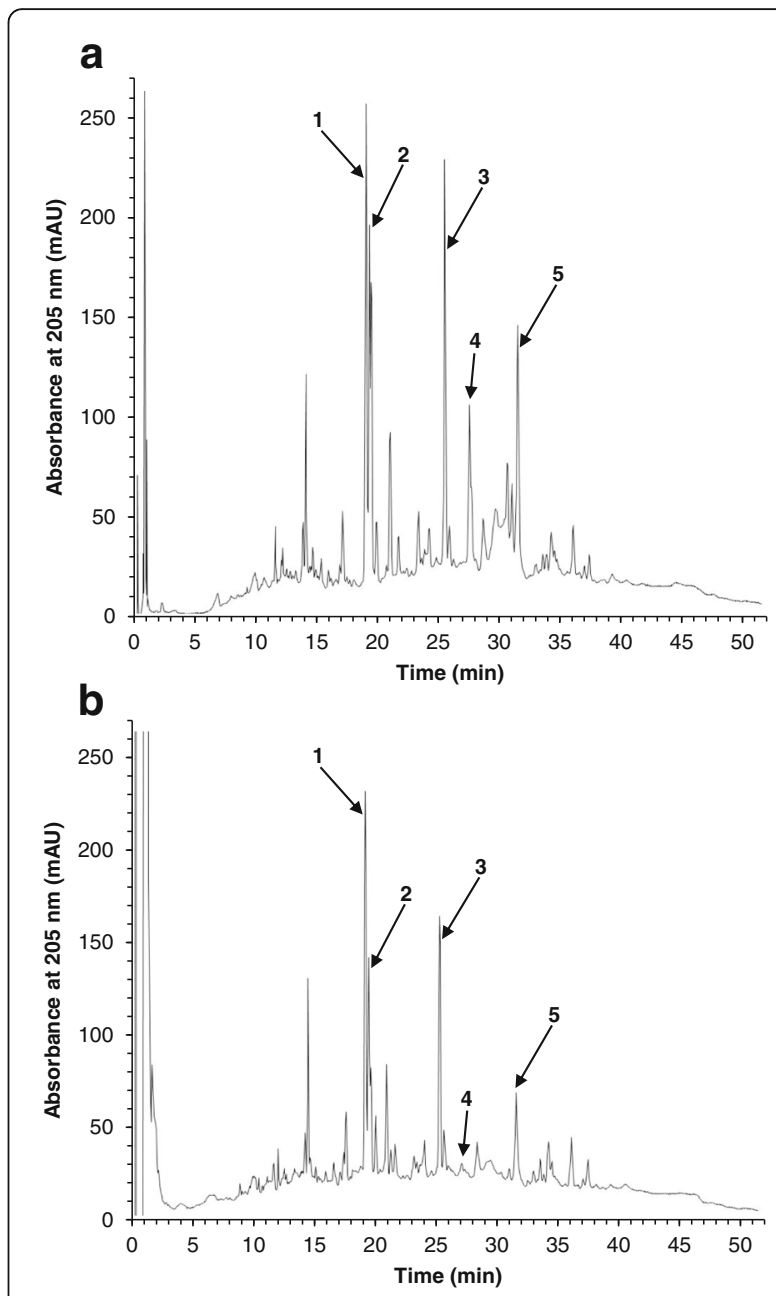

Fig. 2 Analytical reversed-phase HPLC traces of a methanolic extract of T. carbonaria cerumen $(2 \mathrm{mg} / \mathrm{mL})$, in the absence $\mathbf{a}$ and presence $\mathbf{b}$ of the free radical initiator, AAPH ( $80 \mathrm{mg} / \mathrm{mL})$. Peak intensities that decreased in the presence of AAPH (numbered arrows) indicate constituent compounds that scavenged AAPH-derived free radicals after $8 \mathrm{~h}$

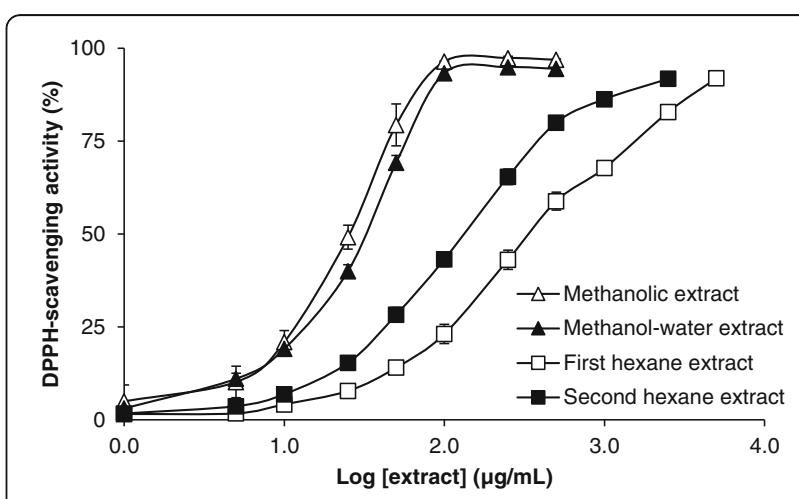

Fig. 3 Free radical-scavenging effects of $T$. carbonaria cerumen extracts, measured using a colorimetric assay (mean \pm SEM). Following multi-solvent extraction of the methanolic extract, the methanol-water cerumen extract scavenged DPPH with greater potency than the first and second hexane extracts $(P<0.05 ; n=3)$ 

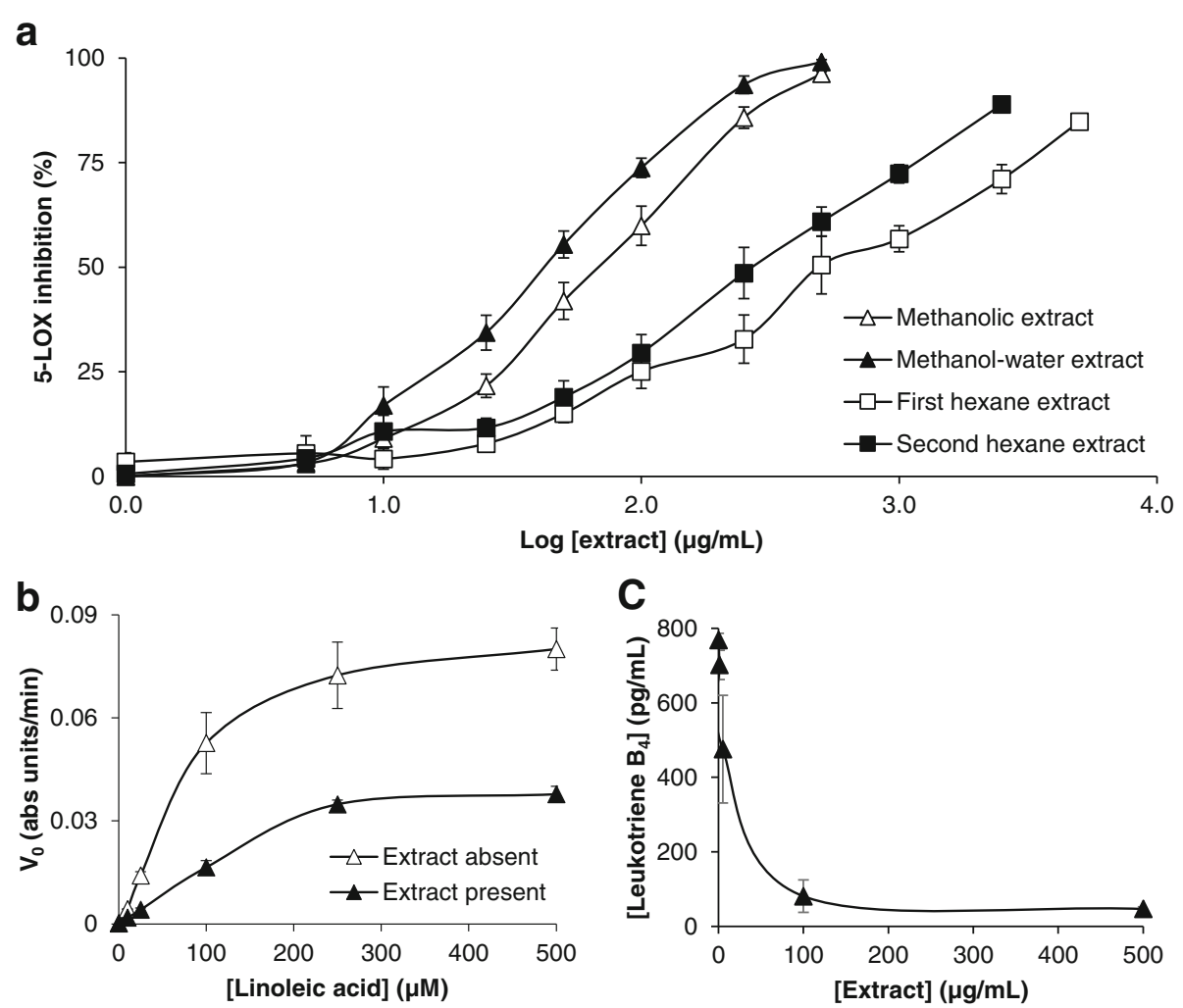

Fig. 4 Inhibitory effects of T. carbonaria cerumen on the pro-inflammatory 5-LOX-LTB 4 signaling pathway in vitro (mean \pm SEM). A methanolic cerumen extract dose-dependently inhibited the 5-LOX-mediated oxidation of linoleic acid (a), through reduced $V_{\max }$ and increased $\mathrm{K}_{\mathrm{m}}(\mathbf{b} ; P<0.05 ; n=3)$. The extract additionally inhibited $\mathrm{LTB}_{4}$ production in human neutrophils stimulated with $2 \mu \mathrm{M}$ ionomycin $(\mathbf{c} ; n=4)$. Following multi-solvent extraction, the methanol-water cerumen extract inhibited 5-LOX activity with greater potency than the first and second hexane extracts $(a ; P<0.05 ; n=3)$

$\mathrm{LTB}_{4}$ production in isolated human neutrophils, but with greater potency than it inhibited the 5-LOXmediated oxidation of linoleic acid in the colorimetric assay $\left(\mathrm{IC}_{50}=13.3 \pm 5.3 \mu \mathrm{g} / \mathrm{mL}\right.$; Fig. $\left.4 \mathrm{c}\right)$. Following multisolvent extraction of the methanolic extract, the resultant methanol-water extract inhibited cell-free 5-LOX activity with comparable potency $\left(\mathrm{IC}_{50}=42.8 \pm 4.6 \mu \mathrm{g} / \mathrm{mL}\right)$; which was greater than the first and second hexane extracts $\left(\mathrm{IC}_{50}=427.5 \pm 76.2 \mu \mathrm{g} / \mathrm{mL}\right.$ and $239.3 \pm 40.7 \mu \mathrm{g} / \mathrm{mL}$ respectively; $P<0.05$; Fig. 4a). Kojic acid, used as a standard 5-LOX inhibitor, inhibited this enzyme with high potency $\left(\mathrm{pIC}_{50}=1.08 \pm 0.038 \mu \mathrm{g} / \mathrm{mL}\right)$.

\section{Composition of a methanol-water extract of $T$. carbonaria cerumen}

Analysis of the methanol-water extract using reversedphase HPLC revealed that it was a complex mixture of numerous compounds (Fig. 5).

By comparison to known compounds, Peak 1 was identified as gallic acid, while the remaining constituents could only be assigned to compound classes (Table 1). The majority of main compounds belong to the flavanone and phenolic classes of natural product.

\section{Discussion}

Propolis and cerumen are plant-derived bee products that exhibit a broad range of chemical and biological properties, regardless of their geographical origins. Although honeybee propolis is considered an ancient folk medicine, the recent popularity of alternative medicines and neutraceuticals has seen research and commercial interest in propolis and cerumen come to the fore. This study aimed to investigate selected anti-oxidant and anti-inflammatory properties of cerumen collected from Australian native stingless bees; a natural product that has not been widely studied. We subsequently found that polar extracts of $T$. carbonaria cerumen possessed potent free radical-scavenging properties, and exhibited inhibitory effects on the 5 -LOX-LTB 4 signaling pathway in vitro. The polar methanol-water extracts were, on average, 10.6- and 4.9-fold more potent that the lower polarity first hexane and second hexane extracts, respectively, in our assays.

It is widely reported that propolis of diverse global origins exert anti-oxidant effects [1, 4, 24]. In particular, propolis extracts have previously been found to scavenge reactive oxygen species (ROS) and synthetic free radicals, inhibit lipid peroxidation, reduce ferric $\left(\mathrm{Fe}^{3+}\right)$ and 


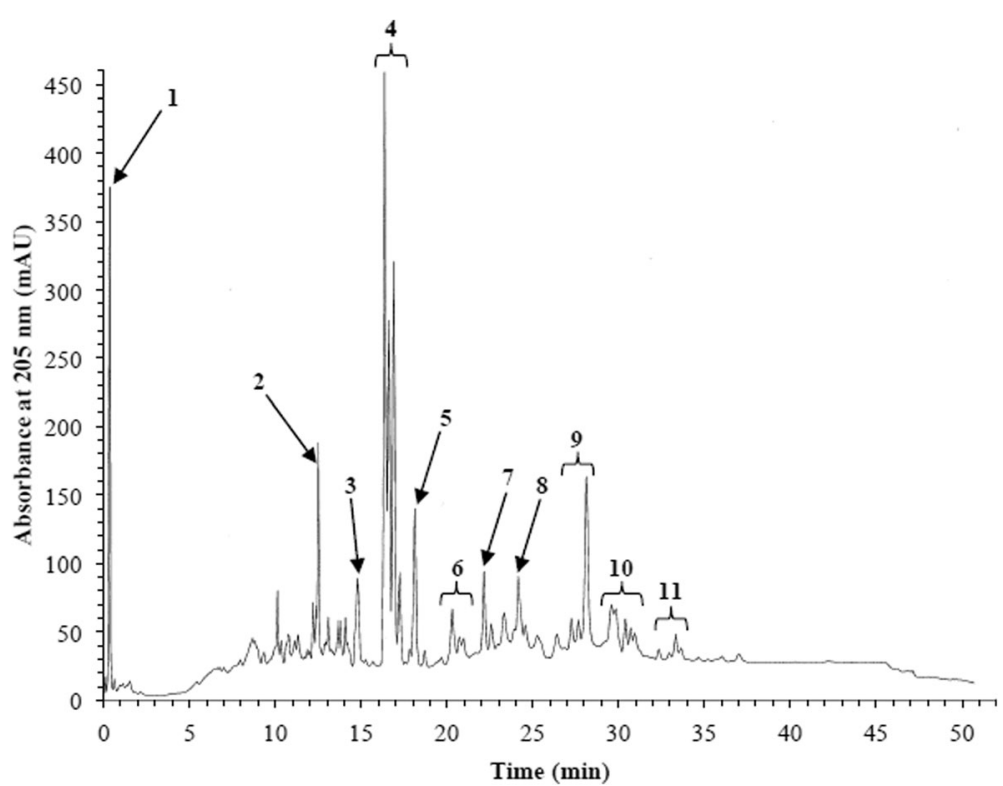

Fig. 5 Analytical reversed-phase HPLC trace of a methanol-water extract of T. carbonaria cerumen. Major compounds in the areas highlighted (1-11) were identified where possible, by comparison to known compounds

cupric $\left(\mathrm{Cu}^{2+}\right)$ ions and elicit metal-chelating effects in vitro $[5,11,25-31]$. In this study, we demonstrated that $T$. carbonaria cerumen also possessed free radicalscavenging properties, evidenced by the ability of its polar extracts to scavenge AAPH and DPPH in cell-free assays. However, whilst the anti-oxidant properties of propolis are often correlated with the phenolic acid and flavonoid content of its extracts [5, 11, 25-29, 31], $T$. carbonaria cerumen comprises a unique chemical profile. Previous gas chromatography-mass spectrometry (GC-MS) analysis of $T$. carbonaria cerumen extracts by our group showed that its chemical profile differed from New Zealand propolis and did not contain CAPE [17], a compound regarded to be largely responsible for the anti-oxidant and anti-inflammatory properties of temperate, honeybee propolis [32,33]. Further studies are required to investigate whether $T$. carbonaria cerumen may exert similar, and additional, anti-oxidant effects in cell-based systems. Gallic acid, one of the compounds identified in cerumen, was previously reported by our group to inhibit 5-LOX activity $\left(\mathrm{pIC}_{50}=5.62 \pm 0.35 \mu \mathrm{g} / \mathrm{mL}\right)$ [17]. The methanolwater cerumen extract had 7.6-fold and 39.6-fold lower potency for inhibition of 5-LOX compared to gallic acid and kojic acid, respectively. Bioactivityguided fractionation of $T$. carbonaria polar extracts are ongoing to elucidate the remainder of its bioactive constituents.

Table 1 Major constituents in the methanol-water extract of T. carbonaria cerumen as determined by HPLC-MS and spectral comparison to known compounds

\begin{tabular}{llll}
\hline Major constituent & Molecular Weight & Major Fragment lon & Identity \\
\hline 1 & 170 & & Gallic Acid \\
2 & 302 & 229 & O-methyl-aromadendrin \\
3 & 422 & 329 & Flavone \\
4 & 270 & 167 & dihydroxydihydroflavone \\
5 & 424 & 285 & Flavone \\
6 & 454 & 329 & Flavone \\
7 & 540 & 453 & Flavone \\
8 & 540 & 427 & Flavone \\
9 & 522 & 387 & Flavone \\
10 & 552 & 271 & Flavone \\
\hline
\end{tabular}


Eicosanoids such as $\mathrm{LTB}_{4}$ are pro-inflammatory signaling molecules produced from the enzyme-catalyzed metabolism of arachidonic acid (AA). Upon liberation from phospholipids by phospholipase $\mathrm{A}_{2}, \mathrm{AA}$ is oxidized to $\mathrm{LTB}_{4}$ via an intermediate precursor, $\mathrm{LTA}_{4}$, in a pathway catalyzed by 5 -LOX and $\mathrm{LTA}_{4}$ hydrolase [34]. In the present study, we found that a methanolic extract of $T$. carbonaria cerumen inhibited the pro-inflammatory 5LOX-LTB 4 signaling pathway in vitro. In cell-free assays, the extract dose-dependently inhibited the 5-LOXmediated oxidation of linoleic acid, by reducing the maximal reaction velocity and the affinity of 5-LOX to its substrate. These findings collectively suggest that the effects of the extract on 5-LOX resembled a mixture of competitive and non-competitive enzyme inhibition [35]. Using a cell-based model of human inflammation, the cerumen extract additionally suppressed $\mathrm{LTB}_{4}$ production by ionomycin-stimulated neutrophils. Our results coincide with others who demonstrated that an ethanol extract of Brazilian green propolis inhibited the release of cysteinyl leukotrienes, $\mathrm{LTC}_{4}, \mathrm{LTD}_{4}$ and $\mathrm{LTE}_{4}$, in peripheral leukocytes of patients with allergic rhinitis [36]. However, since the $T$. carbonaria cerumen extract inhibited neutrophilderived $\mathrm{LTB}_{4}$ production with five-fold greater potency than cell-free 5-LOX activity $\left(\mathrm{IC}_{50}=13.3 \pm 5.3 \mu \mathrm{g} / \mathrm{mL}\right.$ versus $\mathrm{IC}_{50}=67.1 \pm 9.6 \mu \mathrm{g} / \mathrm{mL}$, respectively), we hypothesize that its mechanism of action may not be specific to 5-LOX inhibition. Although it is unclear whether propolis and cerumen may inhibit $\mathrm{LTB}_{4}$ synthesis by exerting additional effects on phospholipase $\mathrm{A}_{2}$ or $\mathrm{LTA}_{4}$ hydrolase enzymes, it has been suggested that their anti-oxidant properties may assist in suppressing eicosanoid synthesis, by non-specifically scavenging the peroxy systems implicated in AA metabolism [37].

\section{Conclusion}

The aim of the present study was to investigate antioxidant and anti-inflammatory properties of polar extracts of cerumen from Australian native stingless bees, T. carbonaria. The study demonstrated that cerumen exerted potent free radical-scavenging effects, was a mixed enzyme inhibitor of 5-LOX, and reduced the $\mathrm{Ca}^{2+}$-ionophore-induced production of $\mathrm{LTB}_{4}$ from human neutrophils in vitro. Polar constituents of cerumen belonged primarily to flavanone and phenolic classes of compound. Further investigation is needed to determine whether the extracts will provide therapeutic benefits for medical conditions in which oxidative stress and inflammation are implicated.

\section{Abbreviations}

5-LOX: 5-lipoxygenase; AAPH: 2,2-azobis(2-methylpropionamidine) dihydrochloride; CAPE: caffeic acid phenethyl ester; DMSO: dimethyl sulfoxide; DPPH: 1,1-diphenyl-2-picrylhydrazyl; HPLC: High-Performance Liquid Chromatography; LTB 4 : leukotriene B4; PBS: Dulbecco's PhosphateBuffered Saline; T. carbonaria: Tetragonula carbonaria.

\section{Acknowledgements}

The authors thank the participants who provided blood samples for this study, Dr. Tim Heard for supply of T. carbonaria cerumen, and Mr. Daniel Meloncelli for conducting the 5-LOX inhibitory assay using kojic acid.

\section{Funding}

This research was supported by scholarships and grants provided by the National Health and Medical Research Council, Queensland Government Department of Science, Information Technology and Innovation, and the Inflammation and Healing Research Cluster of the University of the Sunshine Coast. None of the funding bodies contributed to the study design; collection, analysis and interpretation of data; in the writing of the report; or in the decision to submit the article for publication.

\section{Availability of data and materials}

The datasets supporting the conclusions of this article are included within the article. Residual cerumen from this study is stored frozen at the University of the Sunshine Coast.

\section{Competing interests}

The authors declare that they have no competing interests.

\section{Authors' contributions}

$\mathrm{KDH}, \mathrm{PRB}, \mathrm{SMO}$ and FDR designed the study and critically revised the manuscript. $\mathrm{KDH}, \mathrm{PRB}$ and $\mathrm{SMO}$ carried out the chemical analysis of propolis. $\mathrm{KDH}$ and FDR carried out the bioactivity assays. All authors read and approved the final manuscript.

\section{Consent for publication}

Not applicable.

\section{Ethics approval and consent to participate}

All procedures performed in studies involving human participants were in accordance with the ethical standards of the institutional and/or national research committee (University of the Sunshine Coast Human Research Ethics Committee, (S/12/389) and with the 1964 Helsinki declaration and its later amendments or comparable ethical standards. Informed consent was obtained from all individual participants included in the study.

\section{Publisher's Note}

Springer Nature remains neutral with regard to jurisdictional claims in published maps and institutional affiliations.

\section{Author details}

${ }^{1}$ Inflammation and Healing Research Cluster, Faculty of Science, Health, Education and Engineering, School of Health and Sport Sciences, University of the Sunshine Coast, Maroochydore, QLD 4558, Australia. ${ }^{2}$ GeneCology Research Centre, Faculty of Science, Health, Education and Engineering, University of the Sunshine Coast, Maroochydore, QLD, Australia.

Received: 21 December 2016 Accepted: 21 April 2017

Published online: 26 April 2017

\section{References}

1. Toreti VC, Sato HH, Pastore GM, Park YK. Recent progress of propolis for its biological and chemical compositions and its botanical origin. Evid-Based Complement Alternat Med. 2013;2013:697390.

2. Simone-Finstrom M, Spivak M. Propolis and bee health: the natural history and significance of resin use by honey bees. Apidologie. 2010;41:295-311.

3. Castaldo S, Capasso F. Propolis, an old remedy used in modern medicine. Fitoterapia. 2002;73:S1-6

4. Sforcin JM, Bankova V. Propolis: is there potential for the development of new drugs? J Ethnopharmacol. 2011;133:253-60.

5. Kumazawa S, Hamasaka T, Nakayama T. Antioxidant activity of propolis of various geographic origins. Food Chem. 2004;84:329-39.

6. Iyyam Pillai S, Palsamy P, Subramanian S, Kandaswamy M. Wound healing properties of Indian propolis studied on excision wound-induced rats. Pharm Biol. 2010;48:1198-206.

7. de Moura SAL, Negri G, Salatino A, Lima LD, Dourado LP, Mendes JB, Andrade SP, Ferreira MA, Cara DC. Aqueous extract of Brazilian green propolis: primary components, evaluation of inflammation and wound 
healing by using subcutaneous implanted sponges. Evid-Based Complement Alternat Med. 2011;2011:748283.

8. Massaro CF, Simpson JB, Powell D, Brooks P. Chemical composition and antimicrobial activity of honeybee (Apis mellifera ligustica) propolis from subtropical eastern Australia. Sci Nat. 2015a;1 20:86.

9. Petrova A, Popova M, Kuzmanova C, Tsvetkova I, Naydenski H, Muli E, Bankova V. New biologically active compounds from Kenyan propolis. Fitoterapia. 2010;81:509-14.

10. Oldoni TLC, Cabral ISR, Regitano d'Arce MAB, Rosalen PL, Ikegaki M, Nascimento AM, Alencar SM. Isolation and analysis of bioactive isoflavonoids and chalcone from a new type of Brazilian propolis. Separ Purif Technol. 2011;77:208-13.

11. Abu-Mellal A, Koolaji N, Duke RK, Tran VH, Duke CC. Prenylated cinnamate and stilbenes from Kangaroo Island propolis and their antioxidant activity. Phytochemistry. 2012;77:251-9.

12. Koolaji N, Abu-Mellal A, Tran VH, Duke RK, Duke CC. Synthesis of C- and Oprenylated tetrahydroxystilbenes and O-prenylated cinnamates and their action towards cancer cells. Eur J Med Chem. 2013;63:415-22.

13. Dollin AE, Dollin LJ, Sakagami SF. Australian stingless bees of the genus Trigona (Hymenoptera: Apidae). Invertebr Taxon. 1997;11:861-96.

14. Milborrow BV, Kennedy JM, Dollin A. Composition of wax made by the Australian stingless bee Trigona australis. Aust J Biol Sci. 1987;40:15-25.

15. Wallace HM, Trueman SJ. Dispersal of Eucalyptus torelliana seeds by the resin-collecting stingless bee, Trigona carbonaria. Oecologia. 1995;104:12-6.

16. Leonhardt SD, Wallace HM, Schmitt T. The cuticular profiles of Australian stingless bees are shaped by resin of the eucalypt tree Corymbia torelliana. Austral Ecol. 2011;36:537-43.

17. Massaro FC, Brooks PR, Wallace HM, Russell FD. Cerumen of Australian stingless bees (Tetragonula carbonaria): gas chromatography-mass spectrometry fingerprints and potential anti-inflammatory properties. Naturwissenschaften. 2011;98:329-37.

18. Massaro CF, Katouli M, Grkovic T, Vu H, Quinn RJ, Heard TA, Carvalho C, ManleyHarris M, Wallace HM, Brooks P. Anti-staphylococcal activity of C-methyl flavanones from propolis of Australian stingless bees (Tetragonula carbonaria) and fruit resins of Conymbia torelliana (Myrtaceae). Fitoterapia. 2014;95:247-57.

19. Massaro CF, Smyth TJ, Smyth WF, Heard T, Leonhardt SD, Katouli M, Wallace HM, Brooks P. Phloroglucinols from anti-microbial deposit-resins of Australian stingless bees (Tetragonula carbonaria). Phytother Res. 2015b;29:48-58.

20. Massaro FC, Brooks PR, Wallace HM, Nsengiyumva V, Narokai L, Russell FD. Effect of Australian propolis from stingless bees (Tetragonula carbonaria) on pre-contracted human and porcine isolated arteries. PLoS One. 2013;8:e81297.

21. Zhang YP, Shi SY, Xiong X, Chen XQ, Peng MJ. Comparative evaluation of three methods based on high-performance liquid chromatography analysis combined with a 2,2'-diphenyl-1-picrylhydrazyl assay for the rapid screening of antioxidants from Pueraria lobata flowers. Anal Bioanal Chem. 2012;402:2965-76.

22. Anthon GE, Barrett DM. Colorimetric method for the determination of lipoxygenase activity. J Agr Food Chem. 2001;49:32-7.

23. Russell FD, Windegger T, Hamilton KD, Cheetham NWH. Effect of the nove wound healing agent, OPAL A on leukotriene $B_{4}$ production in human neutrophils and 5-lipoxygenase activity. Wound Pract Res. 2011;19:200-3.

24. Daleprane JB, Abdalla DS. Emerging roles of propolis: antioxidant, cardioprotective, and antiangiogenic actions. Evid-Based Complement Alternat Med. 2013;2013:175135.

25. Gregoris E, Stevanato R. Correlations between polyphenolic composition and antioxidant activity of venetian propolis. Food Chem Toxicol. 2010;48:76-82.

26. Gülçin I, Bursal E, Şehitoğlu MH, Bilsel M, Gören AC. Polyphenol contents and antioxidant activity of lyophilized aqueous extract of propolis from Erzurum. Turkey Food Chem Toxicol. 2010;48:2227-38.

27. Teixeira ÉW, Message D, Negri G, Salatino A, Stringheta PC. Seasonal variation, chemical composition and antioxidant activity of Brazilian propolis samples. Evid-Based Complement Alternat Med. 2010;7:307-15.

28. Mello BCB, Hubinger MD. Antioxidant activity and polyphenol contents in Brazilian green propolis extracts prepared with the use of ethanol and water as solvents in different pH values. Int J Food Sci Technol. 2012;47:2510-8.

29. da Silva Frozza CO, Garcia CSC, Gambato G, de Souza MDO, Salvador M, Moura S, Padilha FF, Seixas FK, Collares T, Borsuk S, Dellagostin OA, Henriques JAP, Roesch-Ely M. Chemical characterization, antioxidant and cytotoxic activities of Brazilian red propolis. Food Chem Toxicol. 2013:52:137-42.

30. Campos JF, dos Santos UP, Macorini LFB, de Melo AMMF, Balestieri JBP, Paredes-Gamero EJ, Cardoso CAL, de Picoli SK, dos Santos EL. Antimicrobial, antioxidant and cytotoxic activities of propolis from Melipona orbignyi (Hymenoptera, Apidae). Food Chem Toxicol. 2014;65:374-80.

31. Souza SA, Dias TLMF, Silva TMG, Falcão RA, Alexandre-Moreira MS, Silva EMS, Camara CA, Silva TMS. Chemical composition, antinociceptive and free radical-scavenging activities of geopropolis from Melipona subnitida Ducke (Hymenoptera: Apidae: Meliponini). Sociobiol. 2014;61:560-5.

32. Sud'ina GF, Mirzoeva OK, Pushkareva MA, Korshunova GA, Sumbatyan NV, Varfolomeev SD. Caffeic acid phenethyl ester as a lipoxygenase inhibitor with antioxidant properties. FEBS Lett. 1993;329:21-4.

33. Boudreau LH, Maillet J, LeBlanc LM, Jean-François J, Touaibia M, Flamand N, Surette ME. Caffeic acid phenethyl ester and its amide analogue are potent inhibitors of leukotriene biosynthesis in human polymorphonuclear leukocytes. PLoS One. 2012;7:e31833.

34. Kim C, Kim J, Kim J. Cytosolic phosopholipase A2, lipoxygenase metabolites, and reactive oxygen species. BMB Rep. 2008:41:555-9.

35. Ochs RS. Understanding enzyme inhibition. J Chem Educ. 2000;77:1453-6.

36. Tani H, Hasumi K, Tatefuji T, Hashimoto K, Koshino H, Takahashi S. Inhibitory activity of Brazilian green propolis components and their derivatives on the release of cys-leukotrienes. Bioorg Med Chem. 2010;18:151-7.

37. Mirzoeva OK, Calder PC. The effect of propolis and its components on eicosanoid production during the inflammatory response. Prostag Leukotr Ess. 1996:55:441-9.

\section{Submit your next manuscript to BioMed Central and we will help you at every step:}

- We accept pre-submission inquiries

- Our selector tool helps you to find the most relevant journal

- We provide round the clock customer support

- Convenient online submission

- Thorough peer review

- Inclusion in PubMed and all major indexing services

- Maximum visibility for your research

Submit your manuscript at www.biomedcentral.com/submit
C Biomed Central 